\title{
TACTICAL USE AND ABUSE OF DEPOSITIONS UNDER THE FEDERAL RULES*
}

Prior to the adoption of the Federal Rules of Civil Procedure in 1938 pretrial discovery was comparatively rare in the federal courts. ${ }^{1}$ Adequate machinery for unearthing facts and paring issues down to those actually in dispute was sorely lacking. Lawyers often proceeded to trial with only the slightest knowledge of their opponent's case. Only in the courtroom could they determine whether their clients should have settled long before. The outcome of litigation often hinged on the ability of counsel to produce surprise evidence and their deftness at countering the tricks of their opponents.?

The new Rules sought to replace this ordeal of legal wit by a clear and relatively easy method of getting at the facts as soon as possible after an action was instituted. ${ }^{3}$ Added reason for the change lay in the adoption of a new approach to pleading which was simple in form but short on information.* To meet these needs, Rules 26 through $37^{5}$ provided for depositions, inter-

\footnotetext{
* Much of the material in this comment is the product of interviews with judges, lawyers and stenographic reporters. Because of the confidential nature of the matters discussed in these interviews no documentation can be made of views stemming from personal experience or of cases not published in official reports. However, no material has been included which has not be corroborated by the experience of others. Among those interviewed have been judges on the Court of Appeals for the Second Circuit, the District Court for the Southern District of New York, the Court of Appeals of the State of New York, the Appellate Division for the First Department of the State of New York; fourteen practicing lawyers in New York City; and five stenographic reporters in New York City and New Haven, Conn. Original statistics have come from the Docket Files for the District Courts for the Southern District of New York and the District of Connecticut, and from the records kept by stenographic reporters in New York City and New Haven, Conn.

1. See 2 Moore, Federal Practice 2445-55 (1st ed. 1938); Dyer-Suniti, Federni Examinations Before Trial $\$ 58$ (1939). The depositions available in the federal courts prior to the new Rules fell into narrowly defined categories, virtually unchanged since the Judiciary Act of 1789. These are discussed in Note, 96 U. of PA. L. Rev. 241 (1947).

2. Koch, Depostrions and Discovery under the Federal Rules, 1-2 (Practising Law Institute, Trial Practice Series Mfonograph No. 8, 1946).

3. Typical of this new approach is the statement in Burton v. Weyerhaeuser Timber Co., 1 F.R.D. 571,573 (D. Ore. 1941), where defenses raised at the trial were not disclosed during a pre-trial conference: "I can sympathize with the desire of counsel, experienced in the older forms of practice, to withhold disclosure of such dramatic issues until the midst of trial, but it must be made clear that surprise, both as a weapon of attack and defense, is not to be tolerated under the new Federal procedure".

4. Originally, bills of particulars were continued under the Rules as a compromise solution to the frequent inadequacy of the new "notice pleading." But these were eliminated in the 1948 amendments, leaving only the discovery mechanism to fill gaps in the pleadings. 2 MOORE, Federal Practice $\{12.17$. (2d ed. 1948).

5. The background and scope of the deposition-discovery procedure is thoroughly discussed in Pike \& Willis, The New Federal Deposition-Discozery Procedure, 38 CoL. L. REv. 1179, 1436 (1938). For a survey of the tools of discovery available under the Federal Rules, see Holtzoff, Instruments of Discovery sunder Federal Rules of Citril Procedure, 41 MIICH. L. REv. 205 (1942).
} 
rogatories, physical examinations, production of documents, and admissions. ${ }^{0}$ Of these the deposition machinery is the most significant. ${ }^{7}$ Not only does it

6. The following chart indicates the use of pre-trial discovery devices in actions instituted in a typical federal district. It displays the varying demand for different discovery mechanisms in the major categories of actions. The chart is based on all cases docketcd between Aug. 29, 1946, and Oct. 16, 1948, in the District Court for the District of Connecticut. Figures under the classifications of actions indicate the relative volume of cases of each type docketed from July 1, 1947, through June 30, 1948.

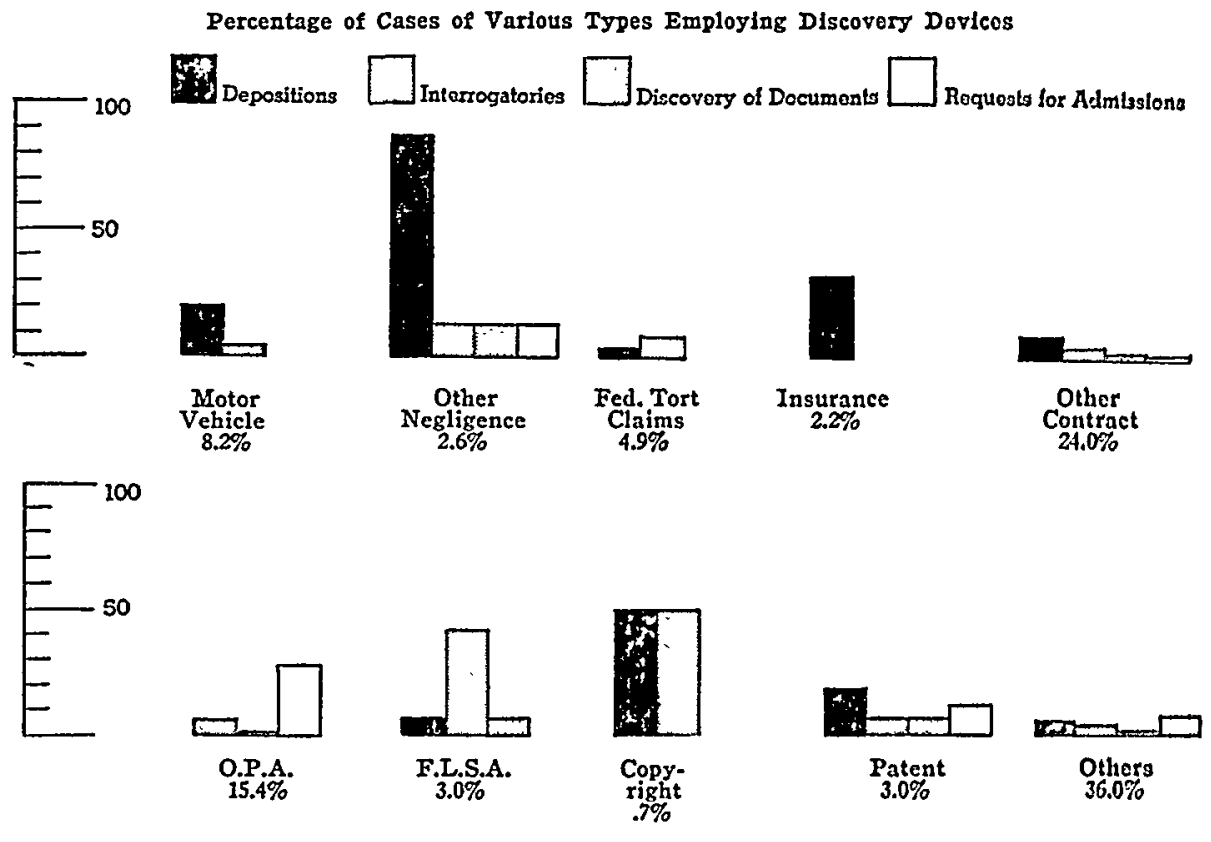

7. The use of depositions became the largest single interlocutory proceeding in cases in the federal courts soon after the Rules were adopted. Stockman, Some Statisticul Observations on the Operation of Discovery and Related Provisions of tue Federal Rules of Civil Procedure 21 (unpublished study in the Administrative Office of the United States Courts, 1942).

\begin{tabular}{lrrrrr}
\multicolumn{3}{c}{ Distribution of Interlocutory Procecdings } & \\
& \multicolumn{1}{c}{ Number* } & \multicolumn{2}{c}{ Pcr } & Cent \\
& 1938 & 1941 & 1938 & 1941 \\
Bills of Particularst & 325 & 312 & 57.4 & 20.1 \\
Depositions & 102 & 507 & 18.0 & 32.6 \\
Inspection & 40 & 76 & 7.1 & 4.9 \\
Depositions and Inspection & 12 & 109 & 72 & 2.1 & 7.0 \\
Interrogatories & 12 & 28 & 2.6 & 1.9 \\
Admissions & 15 & 28 & 8.8 & 4.6 \\
Physical and Mental & 22 & 28 & 1.8 \\
Examination & 50 & 71 & 3.9 & 16.2 \\
Summary Judgment & 566 & 252 & & & \\
Pre-trial Conference & 1455 & & &
\end{tabular}

Id. at 3 .

* These figures computed from a survey of 776 cases in 1938 and 713 cases in 1941 .

$\dagger$ Bills of Particulars were eliminated from federal practice by the amendment of Rule 12(b), effective in 1948. 2 Moore, FEDERAL Practice $\Uparrow 12.17$ (2d ed. 1948). 
provide discovery, but it also serves in other important capacities: preserving the testimony of witnesses who might be unavailable to testify at the time of trial $; 8$ providing a check on adverse witnesses who might try to change their testimony in the courtroom ${ }^{9}$ enabling judges to simplify issues and matters of proof in pre-trial conferences; $;^{10}$ and supporting motions for summary judgment. ${ }^{11}$

The provisions of Rule 26 for the taking of depositions are liberally drawn. ${ }^{12}$ They permit examination of any person or party before trial, and

In 1938, proceedings for depositions were instituted in $10.6 \%$ of all cases docketed in New York, while in 1941 they were instituted in $31.8 \%$ (or 38.9\%, note 9 infra) of the cases. Stockaran, op. cit. supra, at 27. Precise current statistics cannot satisfactorily be determined from the docket files since parties often waive the requirement of filing notice and copies of the deposition with the clerk of the court; however, compare chart in note 6 supra.

8. Rule 26 (d). In some instances this has worked in reverse, excusing the appearance of a witness at trial on the ground that his prior deposition was sufficient to meet the evidentiary needs at trial. Moffett v. Arabian American Oil Co., 8 F.R.D. 566 (S.D.N.Y. 1948) (70-year-old witness who lived in Texas excused from action in New York).

9. Both contradiction of witnesses and perpetuation of testimony require introduction of the deposition into evidence at trial. In New York, in 1941, depositions were introduced in $12.3 \%$ of all cases in which proceedings to take depositions were instituted:

(A)

Percentage of cases in which
depositions takets

All cases

Jones Act

Negligence

Contract

Others
(B)

Percentage of $(A)$ in which depositions were introduced at trial 12.3

13.2

10.8

12.7

13.3
(C)

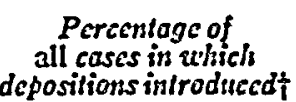

4.8

4.7

5.2

5.5

3.2

man's paper indicate that it should be $38.9 \%$.

In considering these figures it must be borne in mind that few cases reach the trial stage. In 1941 the percentage of disposition without trial was:

$\begin{array}{lc}\text { All cases } & 83.0 \% \\ \text { Jones Act } & 88.5 \\ \text { Negligence } & 73.2 \\ \text { Contract } & 83.1 \\ \text { Others } & \text { (undetermined) }\end{array}$

All figures computed from Stockaran, op. cit. supra note 7, at 4, 11, 27, 37, 38 .

10. Pre-trial conferences are provided for by Rule 16. For a discussion of the operation of pre-trial conferences and the role that depositions play in them, see $3 \mathbf{A f 0 0 2 5}$, Federai Practice 1102-39 (2d ed. 1948).

11. Although the use of depositions as supporting affidavits is provided in Rule $55(c)$, their utility has been cut off in some circuits by current judicial doctrine. E.g., Arnstein v. Porter, 154 F.2d 464 (2d Cir. 1946), 55 YALE L. J. 810 (1946). For an estimate of the current judicial climate, see Kennedy, The Federal Summary Judgment Rulc-Some Recent Developments, 13 Brooksy L. Rev. 5 (1947).

Anticipation of the use of depositions in motions for summary judgment is expressed in Ragland, Discovery Before Trial, 216 (1932); 2 lloore, Federal Practice 2445 (1st ed. 1938); Dyer-Sastre, Federal Exasrrnation before Tras §21 (1939).

12. See generally 2 Moore, Federal Practice 2438-40 (1st ed. 1938).

An instructive comparison to the Federal Rules can be had from an examination of 
grant broad license to inquire into any matter "not privileged" which is "relevant to the subject matter" of the suit. ${ }^{13}$ The procedure for taking depositions is simple and informal. Information obtained need not be admissible as evidence. The function of discovery is served as soon as both parties have equal access to the facts and have had a chance to unearth any evidence they might otherwise have missed. ${ }^{14}$ Though a plaintiff cannot take depositions in order to discover a cause of action, ${ }^{15}$ he is permitted to amend his complaint on the basis of facts he has discovered by deposition. ${ }^{16}$

These broad deposition provisions were designed to achieve the goals attained in jurisdictions employing similar rules. ${ }^{17}$ In those jurisdictions depositions proved effective in ascertaining truth and preventing perjury by permitting the taking of testimony from witnesses while their memories were still fresh and before coaching by counsel. Facts otherwise difficult to prove were made available in a simple, convenient and inexpensive way. Parties were educated in advance of trial as to the value of claims and defenses. This in turn expedited the disposal of litigation, saving the time of the courts, and

the deposition provisions in New York State, for into its courts flow all types of litigation including a sizeable number of stockholders' suits and unfair competition cases. Depositions of parties and witnesses can be taken on the service of notice. However, that notice must contain a list of the subjects to be questioned into. The deponent can move to have the notice vacated or modified, necessitating a court ruling as to the scope of the examination. The deposition is limited to matters "material and necessary in the prosecution or defense of the action." Courts in at least one department have determined this to mean that parties can only be questioned as to matters on which the examiner has the burden of proof. Depositions of non-party witnesses can be taken only under circumstances showing a need to perpetuate their testimony. Depositions by notice cannot call for the production and inspection of documents. Dawson, Examinations Before Trial in State Counts 4-17 (Practising Law Institute, Trial Practice Series No. 5, 1946).

Since 1936 the Judicial Council of New York has recommended a liberalization through legislative amendment of pre-trial examination. Two goals have been sought: one, to permit free examination of the parties to learn their cases fully with no burden of proof limitation; the other, to permit the production and inspection of documents in depositions instituted on notice. Eighth Annual Report of the Judictal Counctr or NEW YoRK 363 (1942). These recommendations have not been adopted. However, a lib. eralizing trend has been started in the courts, and the recent case of Dorros v. Dorros Bros., 274 App. Div. 11, 80 N.Y.S.2d 25 (1st Dep't 1948) has removed the burden of proof limitation on the taking of depositions in commercial cases. See Note, 17 Ford. L. REv. 288 (1948).

13. Rule 26(b).

14. "That the examination may develop useful information by way of discovery which may not be admissible or material upon the precise issue is aside from the point; to the extent that the examination develops useful information it functions successfully as an instrument of discovery, even if it produces no testimony directly admissible." Lewis v. United Air Lines Transport Corp. 27 F. Supp. 946, 947 (D. Conn. 1939).

15. Mebco Realty Holding Co. v. Warner Bros. Pictures, 5 F.R.S. 26a.41, Case 1 (D.N.J. 1942).

16. Conmar Products Corp. v. Lamar Slide Fastener Corp., 5 F.R.S. 26b.31, Case 4 (S.D.N.Y. 1941).

17. Of greatest significance in laying the basis for the new Rules was the study of state and Canadian provisions for discovery, and the careful evaluation of their operation, in Ragland, Discovery Before Trial (1932). 
helping to clear the dockets. Furthermore, depositions facilitated the preparation and trial of cases, preventing surprise at trial, cutting down delays, and narrowing and simplifying the issues to be tried. ${ }^{18}$

By abusing the generous examinations permitted under the Rules, however, parties have prevented the full attainment of these hoped-for goals. The deposition procedure has often turned into a litigation tactic, designed to burden opponents with expense, embarrassment or delay-and, if possible, compel settlement.

\section{DePOSITION MIACHINERY}

Under the Rules any party can take depositions, either by oral examination or by written interrogatories. ${ }^{13}$ Interrogatories, although useful in saving travelling expense where the depositions of distant witnesses are necessary, are not widely used. 20 Lawyers prefer oral depositions so they can observe witnesses' reactions and follow through immediately on any new line of evidence which may be opened. ${ }^{21}$

18. 2 Moore, Feneral Practice 2443-4 (1st ed. 1938) ; Mehrtens, Defositions and Discovery in Florida under the Federal Rules, 1 U. of FLA. L. REv. 149, 151 (1948). Aany of these goals were quickly realized. See Boprs, Strategy and Tecrnigue of DeposiTions 30 (Practising Law Institute, Trial Practice Series Monograph No. 5, P.L.I. 1946).

19. Rule 26(a).

20. In 1941 only $4.7 \%$ of 545 depositions studied in New York were taken on written interrogatories. Stocksran, op. cit. supra note 7, at 33 .

Over a four-and-a-half year period, only one of the depositions transeribed by a stenographic reporter in New York for use in distant forums was taken on written interrogatories. His records show:

\begin{tabular}{|c|c|c|c|}
\hline $\begin{array}{l}\text { Year } \\
1944 \\
1944 \\
1944 \\
1945 \\
1945 \\
1946 \\
1946 \\
1946 \\
1946 \\
* 1946 \\
1947 \\
1947 \\
1947 \\
1947 \\
1948 \\
1948 \\
1948 \\
1948 \\
1948 \\
1949\end{array}$ & $\begin{array}{l}\text { Type of Action } \\
\text { Deficiency Judgment } \\
\text { Deficiency Judgment } \\
\text { Personal Injury } \\
\text { Breach of Contract } \\
\text { Stockholders' Action } \\
\text { Infringement } \\
\text { Infringement } \\
\text { Overpayment to U.S. } \\
\text { Stockholders' Action } \\
\text { Accounting } \\
\text { Property Damage } \\
\text { Overpayment to U.S. } \\
\text { Personal Injury } \\
\text { Property Damage } \\
\text { Commissions } \\
\text { Commissions } \\
\text { Personal Injury } \\
\text { Personal Injury } \\
\text { Property Damage } \\
\text { Personal Injury }\end{array}$ & $\begin{array}{l}\text { Where Peıding } \\
\text { Florida } \\
\text { Florida } \\
\text { Vermont } \\
\text { Illinois } \\
\text { Nebraska } \\
\text { Illinois } \\
\text { Alinnesota } \\
\text { Washington, D.C. } \\
\text { Massachusetts } \\
\text { Texas } \\
\text { Illinois } \\
\text { Washington, D.C. } \\
\text { Illinois } \\
\text { Nebraska } \\
\text { Mrissouri } \\
\text { Pennsylvania } \\
\text { Washington, D.C. } \\
\text { Florida } \\
\text { California } \\
\text { Connecticut }\end{array}$ & $\begin{array}{c}\text { Cost of Transcribing } \\
\$ 225 \\
120 \\
75 \\
75 \\
450 \\
235 \\
175 \\
350 \\
225 \\
300 \\
75 \\
110 \\
135 \\
105 \\
225 \\
115 \\
135 \\
80 \\
90 \\
70\end{array}$ \\
\hline
\end{tabular}

* On written interrogatories.

21. Depositions by written interrogatories (Rule 31) are to be distinguished from interrogatories to parties (Rule 33). The former type are generally direted toward witnesses who are distant from the locale of the action; they assume many of the attributes of oral depositions, including oral testimony and cross examination-the difference being that the stenographic reporter poses the questions instead of counsel for either party. The 
Depositions by oral examination can be taken with no more formality than the serving of a notice on all parties. ${ }^{22}$ The notice states only the time and place of the deposition and does not include the subject matter to be investigated. $^{23}$ It can be served at any time after the commencement of the action, except that a plaintiff cannot serve notice without leave of court until twenty days have expired from the filing of his complaint. ${ }^{24}$

The scope of examination is virtually unlimited. ${ }^{25}$ Only matters which are "privileged" under the applicable common-law and statutory rules of evidence are specifically excluded. ${ }^{26}$ Otherwise the proponent may inquire into anything "relevant to the subject matter involved in the pending action." Although courts have sometimes ruled certain areas of examination irrelevant,"77

latter type, interrogatories to parties, are of primary utility in pinning down the issues in complex actions where broad allegations are used in the complaint. They may be used independent of, and in addition to, depositions. They have inherent disadvantages for the proponent in that they permit studied, carefully phrased answers which may often evade the main thrust of the questions. Furthermore, interrogatories to parties provide protections for the deponent which are not available in practice when oral examinations arc taken: the deponent has time to figure out evasions to questions on later interrogatorics, so that the proponent cannot effectively follow up leads to evidence; the deponent can object to questions before he must answer them; and the number of interrogatories can be limited by court order if they will entail too much expense for the deponent. For a critical evaluation of interrogatories under Rule 33, see Caskey \& Young, Some Further Comments upon Rule 33 of the Federal Rules of Civil Procedure, 33 VA. L. Ruv. 125 (1947).

22. Rule 30(a).

23. E.g., United States ex rel. Edelstein v. Bruşsell Sewing Machine Co., 3 F.R.D. 87 (S.D.N.Y. 1943).

24. Rule 26(a). Rule 33 permits depositions to be taken even though interrogatories have been answered, and vice versa, subject to protective orders upon motion to the court. See Howard v. States Marine Corp., 1 F.R.D. 499 (S.D.N.Y. 1940) (scope of deposition after interrogatories limited); Currier v. Currier, 6 F.R.S. 33.61, Case 1 (S.D.N.Y. 1942) (interrogatories prohibited after depositions had been taken).

As originally adopted, the Rules provided that notice could not be served until the defendant served his answer, without leave of court. This was replaced by the 20 day rule in the 1948 amendments. See note 73 infra and accompanying text.

25. The most renowned dispute as to limitations on the scope of depositions surrounds Hickman v. Taylor, 329 U.S. 495 (1947), wherein statements of witnesses obtained by counsel prior to the institution of the action were held to be outside the proper scope of examination in the absence of showing "good cause". The extent to which scope is limited in this direction is not yet fully resolved. An excellent survey of the recent ramifications of the decision in Hickman v. Taylor is contained in Note, 62 Hunv. L. Rev. 269 (1948). See Discovery Procedure Sympositm, 5 F.R.D. 403 (1946).

General surveys of the limitations on scope of examination are to be found in Koctr, op. cit. supra note 2, at 30-40; Mehrtens, Depositions and Discovery in Florida under the Federal Rules, 1 U. of FLA. L. REv. 149, 165-73 (1948); Holtzoff, op. cit. supra note 5, at 208-9; Pike \& Willis, Federal Discovery in Operation, 7 U. of Cur. L. REv. 297 (1940); Note, 50 Yale L. J. 708 (1941).

26. Engl v. Aetna Life Ins. Co., 139 F.2d 469 (2d Cir. 1943) (doctor-patient privilege).

27. United States v. Cotton Valley Operators Committee, 75 F. Supp. 1 (W.D. Lat 1948) (motion to prevent defendant's taking depositions of Attorney General and U.S. Attorney in order to show that antitrust suit was not filed in good faith granted) ; Camp- 
on the whole they have given "relevant" the broadest definition. 28

Rule 30 (b) authorizes limitations on the scope of the proposed examination if the person whose deposition is to be taken can show that it will otherwise lead to "annoyance, embarrassment, or oppression". However, orders limiting the examination have been issued only occasionally ${ }^{29}$ and, in general, are hard to obtain. ${ }^{30}$ This is especially true where the prospective deponent and the court can only guess what the exact scope of examination will be. ${ }^{31}$ Even where the proposed scope is known, the prerequisites for obtaining a protective order are difficult to establish. ${ }^{32}$ Courts tend to instruct applicants to move for an order only if an abuse occurs during the actual talking of the deposition. 33

The deponent can seek a protective order during the taking of the deposition under Rule 30 (d) when it appears that the questioning is being conducted in bad faith, or "in such a manner as unreasonably to annoy, embarrass, or oppress." ${ }^{34}$ Here, too, it is difficult to get adequate protection. Proving the

bell v. American Fabrics Co., 2 F.R.D. 204 (E.D.N.Y. 1942) (motion to inspect and copy accounts and records not material or relevant to the issues: denied). In at least one instance courts have been more ready to limit examinations than the Rules seem to have contemplated: Blumenthal v. Lukacs, 5 F.R.S. 26b.31, Case 9 (S.D.N.Y. 1942) ("highly conjectural" that matters sought relate to the issue; "relevancy to the issue is still the test").

28. Mackerer v. New York Central R.R., 1 F.R.D. 408 (E.D.N.Y. 1940) ("matters generally bearing on the issue"); Lavereet v. Continental Briar Pipe Co., 25 F.Supp. 80 (E.D.N.Y. 1938) ("broadest type of examination"). For examples of the scope of examination permitted see Bloomer v. Sirian Lamp Co., 8 F.R.S. 26b.31, Case 3 (D. Del. 1944) (stockholders' suit for dissolution-examination of voluminous transactions permitted to unearth possible evidence of mismanagement).

29. Bevemet Mietais, Itda v. Gallie Corp., 7 F.R.S. 34.41, Case 4 (S.D.N.Y. 1943) (where sufficient time and opportunity to obtain a full examination had been provided, motion for continuation of deposition denied; evaminer would not be "materially aided"); Heiner v. North American Coal Corp., 7 F.R.S. 26b.21, Case 1 (W.D. Pa. 1942) (scope of deposition limited upon sufficient showing of oppression: repetition, expense and delay).

30. Even where the face of the complaint raises serious doubts as to the merits of the suit, and despite the fact that depositions will be long and expensive for the defendant, motions to limit examination have been denied. E.g., Piccard v. Sperry Corp., 30 F. Supp. 171 (S.D.N.Y. 1939) (minority stockholder's suit; plaintiff holder of 110 voting trust certificates out of a total of $2,015,565$; other certificate holders had declined joining in the action).

31. E.g., Hirsch v. Glidden Co., 79 F. Supp. 729, 730 (S.D.N.Y. 1948). "It is difficult at this time to place any definite bounds on the examination, other than to say that it should be confined to the issues in the case, and not be allowed to drift into extraneous matters having no relevance to the issues involved."

32. Courts have required that in order for annoyance, embarrassment and oppression to be grounds for a protective order, they must be "unreasonable." E.g., Applieation of Zenith Radio Corp., 4 F.R.S. 30b.21, Case 1 (E.D. Pa. 1941).

33. E.g., French v. Zalstem-Zalessky, 3 F.R.S. 45d.5, Case 1 (S.D.N.Y. 1940); Krier v. Muschel, 29 F.Supp. 482 (S.D.N.Y. 1939).

34. Protective orders may issue as late as during a pre-trial conference, where courts may also order that depositions be taken. Monarch Liquor Corp. v. Schenley Distillers Corp., 5 F.R.S. 26b.21, Case 2 (N.D.N.Y. 1941). See Ulrich v. Ethyl Gasoline Corp., 2 F.R.D. 357 (W.D. Ky. 1942) (ordering compliance with subpoena duccs fecum); 
requisite bad faith is difficult. ${ }^{35}$ Past practice has shown that even if protective orders are obtained, they usually treat limitations on scope gingerly. ${ }^{30}$ These orders at best have been compromises, doing little more than softening the blow for the deponent. ${ }^{37}$

Within the scope of any limiting order a deponent must answer the questions put to him during a deposition, even though the evidence as such may be inadmissible. ${ }^{38}$ Counsel can object to admissibility, but objections are merely noted by the stenographer, and become effective only if the deposition is offered at trial. ${ }^{30}$

When, however, the questions are felt to be unfair or outside the reasonable area of examination, the deponent may attempt to protect himself by refusing to answer. Under Rule 37 the proponent of the question can then either complete the examination as to other matters, or adjourn, and apply for a court ruling on the question. Judges find it difficult to determine the relevance of such questions when presented out of context. They are inclined to order the question answered subject to a later ruling if the answer is offered at trial. The proponent thereby gains entry into possibly long and fruitless avenues of inquiry far from the subject matter of the litigation, or into damaging unrelated matters or secrets to which he is not entitled. The likelihood of an adverse ruling, the delay involved, and the probable liability for all the expenses of the trip to court, have discouraged deponents from seeking selfprotection by refusing to answer questions they consider improper. ${ }^{40}$

Fairwater Transportation Co. v. Chris-Craft Corp., 1 F.R.D. 509 (S.D.N.Y. 1940) (order for production of documents and limiting scope of deposition).

35. See Commercial Solvents Corp. v. Jasspon, 13 F.R.S. 30d.31, Case 1 (S.D.N.Y. 1949).

36. See Heiner v. North American Coal Corp., 3 F.R.D. 63 (W.D.Pa. 1942) (scopo and relevancy impossible to determine; "rely on the ethics and judgment of counsel").

37. See Folley Amusement Holding Corp. v. Randforce Amusement Corp., 4 F.R.S. 26b.31, Case 1 (S.D.N.Y. 1940) ("a reasonable time prior to July, 1934"; "not proper that moving defendants should be required to produce all books, records, documents, contracts, and other papers, but only such as are relevant to the inquiry").

38. As to the application of rules of evidence to depositions see Pike, The Ncze Foderal Deposition-Discovery Procedure and the Rules of Evidentce, 34 ILL. L. Rev. 1 (1939). As an example of matters which may be inquired into which would be excluded at trial see Orgel v. McCurdy, 12 F.R.S. 26b.31, Case 1 (S.D.N.Y. 1948) (liability insurance in automobile injury action).

39. Rules $26(\mathrm{e})$ and 30 (c).

40. Furthermore, once the court has ordered the deponent to answer, even though the deponent feels that the answer will improperly prejudice him, he has no more choice in the matter. Continued refusal can be punished as contempt or by the application of special sanctions fatal to his claims or defenses. These include: an order that the matters about which the questions are asked be taken to be established for the purposes of the action as claimed by the adverse party; an order refusing to allow the disobedient party to support or oppose designated claims or defenses, or to introduce designated evidence; an order striking out pleadings, dismissing the action, or giving judgment by default; and an order for the arrest of the disobedient party. Rule 37 (b) (2). 


\section{DEPOSITIONS IN OPERATION ${ }^{-11}$}

In the majority of cases the discovery machinery provided under the Federal Rules is not abused. However, the nature of the cases themselves more often explains this absence of abuse than any safeguard inherent in the Rules.22 Abuse, when it does occur, generally appears in complex litigation

41. This section is largely based on practical diffculties involved in the preparation of cases for trial, which by their very nature cannot be documented. Insoiar as possible general statements on the operation of depositions are supported by statistical data, but in studying these it should be remembered that statistics are difficult to gather in such a field, and even once gathered only show small facets of the overall picture. Averages and median figures will give some indication of the general operation of depositions but show little of the frequency and character of non-average cases where the difficulties outlined in this section arise. These cases can only be determined from specific examples.

There have been two important empirical studies in the field. Best known, and still heavily relied on, is Ragland, Discovery Before TrLaL (1932). It is a careful statistical study of the use of depositions for discovery in many state jurisdictions. The study was probably the main basis for the inclusion of unlimited depositions in the Federal Rules. But Ragland's work, a sound combination of statistics and the experience of the bench and bar, was published in 1932, and is largely inapplicable as far as the use of depositions under the Federal Rules is concerned. The other study is the extremely thorough statistical survey of the operation of the Federal Rules conducted by Mr. Abram Stockman for the New York Law Society in 1942: Soare Stitistical Onservatio:s 0: the Operation of Discovery and Related Provisions of the Fejeral Rules of Civi Procedure (unpublished, 1942). The only known copy of this paper is in the files of the Administrative Office of the United States Courts, Supreme Court Building, Washington 13, D.C. The study is based on cases in the Southern District of New York and therefore includes a large number of cases under the Jones Act, 41 Sist. 1007 (1920), 46 U.S.C. $\$ 688$ (1946). These cases, seaman's injury actions, present a special need for depositions because of the frequent unavailability of plaintiff and witnesses. Because these actions are limited to shipping areas, and because the problems of the type considered in this comment as they apply to Jones Act cases are in the main similar to negligence actions, no special treatment is given to them here. A critical discussion of the Jones Act is to be found in Comment, 57 YaLE L.J. 243 (1947).

42. The incidence and nature of depositions has changed a considerable degree since the Rules were first drafted. Ragland's figures (sce note 41 suspra) indicated that the overwhelming use of depositions was in automobile injury cases and in other type actions in which the very narrowness of the issues and the prescribed fact situations automatically limited the scope and expense of depositions. Although the use of depositions in these actions today is still heavy, the ratio of these to more complex cases with wealthicr parties and less limited issues has declined. Thus if Ragland's figures gave the draiters of the Rules a sense that on the whole the taking of depositions could not be burdensome and expensive because of their automatically limited scope in the type cases in which they are most generally used, there is ground for a readjustment of viewpoint.

Ragland's figures show the use of discovery (including interrogatories as well as depositions) in Wisconsin state court actions in 1932. As to depositions themselves these figures must be considered only as indicating the general ratio. The comparative 1948 figures show the use of depositions alone.

Cases in which Depositions are Taken

Automobile Accident

Contract

Negligence other than automobile Fraud

$\begin{array}{ccc}1932 \div & 1948(\text { D.Comn. }) \neq & 1948(\text { S.D.N.Y. }) \neq \\ 45 & 14 & 3 \\ 13 & 28 & 24 \\ 8 & 28 & 41 \pi \\ 7 & 4 & 1\end{array}$


where the resources of time, money and counsel make it practicable as a litigation tactic.

\section{Expense ${ }^{43}$}

Large expense in depositions can be a double-barreled evil: it is por sc repugnant to the principle of just, speedy and inexpensive determination of cases $; 4$ and it operates to permit counsel to exert pressure for settlement un-

Divorce*
Account
Promissory Note
Malpractice
Mortgage Foreclosure
Assault and Battery
Cancellation of Deed
Slander or Libel
Conversion
Patent**
Tax
Copyright**
Stockholders' Suit
Statutory Causes of Action ${ }^{* * *}$
Other

\begin{tabular}{ccr}
7 & & \\
6 & 4 & \\
6 & & \\
2 & & \\
1 & & 1 \\
1 & & 1 \\
1 & 6 & 2 \\
& 2 & 4 \\
& 2 & 21 \\
& 8 & 100 \\
\hline 100 & 100 &
\end{tabular}

$\dagger$ Ragland, Discovery Before Trial 28 (1932).

$\$$ Actual count from Civil Dockets, covering all cases in D. Conn. docketed from Aur. 29,1946 , to Oct. 16, 1948, and even numbered cases docketed in S.D.N.Y. from Scpt. 23, 1946, to Dec. 19, 1946. Connecticut figures have been doubled to facilitate comparison.

* Inapplicable to federal courts.

** Inapplicable to state courts.

*** Including suits under Fair Labor Standards Act, Employers' Liability Act, and Selective Service Act.

II Including 23 seamen's actions.

43. The item of expense here considered relates only to the costs usually borno by any party whose deposition is taken. A special problem arises when depositions are taken of experts and specialists who have been hired by one of the parties, because of the inequity of allowing the other side to get expert assistance without having to pay for it. The confusion surrounding Hickman v. Taylor, 329 U.S. 495 (1947), see notc 25 silpra, has precipitated a distinct split among the courts as to whether one party can examine another party's experts. Note, 62 HARv. L. REV. 269 (1948). When depositions of experts are allowed, the soundest suggestion scems to be to make the examining party sharo the expense of the expert's fee. Note, 50 YaLE L.J. 708, 710 (1941).

44. Ragland's figures in 1932 indicated that depositions were inexpensive items in the cost of litigation. He computed the average cost of transcribing depositions to be about $\$ 15.00$, and reported that the highest cost for a deposition he had yet discovered was $\$ 66.60$. Ragland, Discovery Before Trial 172 (1932). Prices everywhere have of course risen since then. In 1941, using Stockman's figures, the average appears to have been about $\$ 80.00$. StockmaN, op. cit. supra note 7 , at 35 . Taking into account the rise in rates for stenographic reporting, the cost today based on Stockman's figures would probably be at least ten or twenty dollars higher. A superficial spot-check of reporters' bill-files today indicates the average to be somewhere over $\$ 130$, but it is doubtful if such a check can produce accurate figures.

The range of costs produces startling figures, for it indicates that depositions can be quite expensive in certain types of cases. One stenographic reporter notes that he has transcribed depositions in a dozen stockholders' suits where the cost ran from $\$ 1000$ to $\$ 5000$ apiece. He reports two extreme stockholders' suits where the bills for transcribing the depositions were $\$ 20,000$ and $\$ 25,000$. 
der the threat of taking depositions which the adverse party can ill afford. For the expense of depositions is not limited to the examiner. Although he usually must pay the cost of transcribing the examination, the deponent pays for his own copies, for his counsel, and for the expense of being away from his work.

In the largest mass of cases-personal injury actions and simple commercial cases-the narrowness of the facts which may be inquired into keeps the cost of taking depositions low. ${ }^{45}$ Furthermore, plaintiffs are often impecunious and want to avoid non-essential expenses, while defendants do not desire to preserve the testimony of opposing witnesses. ${ }^{10}$ Mioreover, because of the volume of cases handled by the negligence and commercial bars in many cities, preparation for trial is usually minimized. The greatest emphasis is placed on handling witnesses before a jury. ${ }^{47}$ Opposing counsel frequently arrive at tacit agreements not to use the deposition procedure unless absolutely necessary.

The expense of depositions becomes an abusive factor where one party is in a position to create a burdensome expense for the other party without fear of the cost to himself. This situation arises, for example, where the examining party is wealthy and the deponent not, or where one party has so few facts that he has little fear of retaliatory depositions. Expense created under these circumstances can be used to force the deponent to a settlement not otherwise possible.

It is in complex commercial cases, such as multistate breach of warranty, unfair competition, and antitrust actions, that the expense of depositions may become unreasonable. ${ }^{48}$ Where expense is essential to an effective prosecution or defense of these actions high cost does not prove misuse of the deposition procedure. ${ }^{49}$ But it can still be staggering.50 In one private antitrust suit for

45. In 1941, using Stockman's figures, the average cost of depositions in negligence actions was $\$ 38.88$. StockNsan, op. cit. sipra note 7, at 35 . In terms of pages the contrast between simple and complex actions is sharp. The longest deposition Stoclman found in negligence actions was 200 pages, while in contract cases it was 1040 pages. Id. at note 29. One lawyer reports a stockholder's action deposition over $\$ 000$ pages long. In a private antitrust action the deposition of only one of many witnesses was 10,630 pages. The cost per page is largely controlled by a statutory minimum rate, but a conservative estimated minimum is about 75 cents for the original and 35 cents per copy. The cost varies upward with the competence of the reporter and the arrangements made as to how quickly transcripts must be supplied.

46. See Bodin, op. cit. stipra note 18, at 28-9.

47. Despite all these factors, in 1941 depositions were taken in $47.9 \%$ of negligence actions and $43.2 \%$ of contract actions, as opposed to an overall 31.8\% (see note 9 stopra) for all types of cases. Stockaran, op. cit. sipra note 7, at 27.

48. Expense does not appear to be a matter of abuse in patent cases, where depositions are generally put to good use. In these cases they are especially valusble to defendants, for they provide an opportunity to learn all the facts surrounding the patent in dispute from the patentee-plaintiff. They are also widely used to establish the affirmative defenses of prior use or prior sale, for the witnesses necessary to establish these are usually spread across the country and would in many cases be hard to produce at trial.

49. This, in fact, is the usual answer to any question about the expense of depositions. See. for example, the answer of Judge Kennedy of the Eastern District of New York to 
treble damages the cost of merely transcribing the testimony of one key witness ran over $\$ 20,000$. To this must be added the cost of counsel for each side plus the cost of the witness' absence from his business. Complexity of the material and the hard feelings which give rise to freqeunt wrangles may require a master to supervise the depositions, adding several hundred dollars a day to the cost. The bulk of the testimony may be so great that lawyers must be assigned to work full-time digesting the testimony in order to get it down to workable length. ${ }^{51}$

The expense of depositions may be exploited most easily in suits such as derivative stockholders' actions. ${ }^{52}$ Here, of course, the availability of evidence

the question of expense in a discussion before the Association of the Bar of the City of New York: " $Q$ : Isn't the deposition procedure turning out to be a very expensive procedure? In other words, you are travelling all over the lot. A judge hesitates very much to say that testimony is irrelevant and immaterial, and the result is you spend weelss and months sometimes in a deposition. ...

"JUDGE KENNEDY: ... The objection of expense I find difficult in meeting, except to say this: that it is unlikely that a case could be as protracted and as involved as the one you put, unless a lot of money is involved in it. If a lot of money were involved in it, the lawyer would be very happy to travel around taking depositions." Kennedy, Discovery Proceedings before the Federal and State Courts 31-2 (talls transcribed by the Commerce Reporting Company, April 26, 1949).

50. Not only are courts often very strict in saddling a party with an expensive production of evidence for discovery purposes, but it has been held that no appeal lies from the courts' orders no matter how extreme they may be. O'Malley v. Chrysler Corp., 160 F.2d 35 (7th Cir. 1947). In that case the district judge insisted that the plaintiff's interrogatories be answered even though the defendant had already spent 90 days and $\$ 10,000$ computing statistics requested. Said the judge: "I am not at all interested in what it cost. If it cost a hundred thousand dollars that doesn't make the slightest difference to me. I don't want to see you waste your money. But I said I thought they were entitled to certain information in order to prepare their case for trial." $I d$. at 42.

It should be possible to have appellate review of extremely unreasonable orders through one of the discretionary writs. 3 Moore, Federaz Practice 1136-8 (2d ed. 1948).

51. In those government antitrust suits which include every suspected violator of the antitrust laws in a particular segment of industry the burden of expense may be compounded in a manner particularly devastating to the small peripheral defendant. Each defendant must pay his pro rata share for copies of depositions which affect his position in such a suit. He must provide counsel at all depositions in which there might be need for cross-examination to clarify points which deal with him. The complexity of proof may make him liable to extensive questioning not only affecting the merits of the claim against him but also as to the other parties defendant.

52. Depositions of corporate officers and directors can be long and drawn out. There are many documents and corporate records which can be called for; discovery to unearth leads to evidence can be extended for many days; and the number of officers and directors of the corporation who can be questioned is large. In one extreme case depositions were taken five days a week for fourteen months. Not only is the actual expense of taking the deposition high, but the cost to the corporation of having its executive personnel absent from their jobs for extended periods of time is heavy.

Plaintiffs do not share the cost of executives being away from their jobs. And by at least two devices currently in use they escape all other expenses, except for cost of counsel, who may be retained on a contingent fee basis so that there is no cash expenditure at all. One is an arrangement with the stenographic reporter who transcribes the deposition, whereby in return for giving the reporter the sizeable business of an ex- 
to a plaintiff from other sources is so limited that depositions are most essential to successful prosecution. Nonetheless, abuse can arise when the imminence of expensive depositions is used for shake-down purposes by plaintiffs who have no intention of pursuing their suits through to trial. ${ }^{53}$ The expense of pre-trial examination in such cases can be so large in comparison to the recovery sought that settlement would be almost mandatory. ${ }^{5:}$

tended deposition in which a defendant usually orders several copies of the transcript, the reporter agrees to supply the plaintiff with a copy gratis. The other practice is for the plaintiff to notify the defendant that the depositions will be taken at times and places which are highly inconvenient to the defendant, and to threaten to use an incompetent secretary from counsel's own office; this usually leads to stipulation by the defendant that it will pay the bills and furnish the reporter. The plaintiff does not have to face much cost because of the possibility that the defendant may take his deposition in turn, for there is little that he can be asked except as to the legitimacy of his standing as a stocl:holder.

53. Rule 23 prohibits the settlement of derivative suits without court approval, and once consent is given the damages involved in the settlement are paid to the corporation for the benefit of all stockholders. Nonetheless, shakedowns are still possible in the inflated attorneys' fees which often constitute a substantial part of such settlements. Moreover, the federal courts almost invariably approve proposed settlements. Hornstein, New Aspects of Stockholders' Derivative Suits, 47 CoL. L. Rev. 1, 22 (1947).

54. One method by which the expense of depositions may be utilized to engineer settlements can be inferred from situations where stockholders' suits have been brought simultaneously in the state and federal courts, presumably in order to use the deposition procedure available under the Federal Rules to aid in the prosecution of the action in the state court. This becomes unfair when settlements in the state courts are permitted without the requirement of court approval or notice to all other stockholders necessary under Rule 23. A plaintiff can combine liberality of deposition-taling with the freedom to settle out of court contrary to the individual rules of both jurisdictions. Courts have had their attention called to this situation, but they have not always been scrupulously careful to prevent it. Compare Bachrach v. General Investment Corp., 31 F.Supp. 84 (S.D.N.Y. 1940) (motion to prohibit taking of depositions granted) and Finkelstein v. Boylan, 33 F.Supp. 657(S.D.N.Y. 1940) (postponed), zitls De Seversly v. Republic Aviation Corp., 2 F.R.D. 183 (E.D.N.Y. 1941) (deposition allowed since sole purpose not shown to be for use in state courts). See also Empire Liquor Corp. v. Gibson Distilling Co., 2 F.R.D. 247 (S.D.N.Y. 1941) (deposition permitted; apparent good faith); Snap Lite Corp. v. Stewart Warner Corp., 40 F. Supp. 776 (S.D.N.Y. 1941) (deposition prohibited; already refused in pending state court action); Mriller-Becker Co. v. MracGowan, 13 F.R.S. 30b.31, Case 2 (S.D.N.Y. 1949) (deposition permitted; parties and remedies not the same as in state court action).

In Mottolese v. Kaufman, 13 F.R.S. 30b.31, Case 1 (2d Cir. 1949), stay of a stoclsholder's derivative action was affirmed on the ground that its prosecution at the same time as a pending state court action on the same cause would unduly burden the defendant. The stay was modified, however, to accommodate the plaintiff's lament that pretrial examination under the state practice would be too restricted. The court gave instructions that depositions under the Rules be allowed if not satisfactorily afforded in the state proceeding. The effect of the Mrottolese ruling is to allow plaintiffs in derivative actions to bring their suits in states with liberal settlement provisions while borrowing the unrestricted federal discovery procedure simply by filing a duplicate complaint in the district court. Frequently duplicate actions are brought simultancously to protect against plagiarism. Allowing this protection, however, is no justification for the important corollary of permitting free choice between the most favorable procedural provisions of the two available forums. Although legitimate stochholders' suits descrve 
The suggestion in Rule $29^{55}$ that money could be saved ${ }^{60}$ by using office stenographers instead of official reporters and by not having the stenographer's notes transcribed unless necessary has not proved to be a workable economy. ${ }^{57}$ Probably the only practical saving in general practice is the waiving of the requirement that the depositions be filed with the clerk of the court, thus saving the cost of having an additional copy made for that purpose.

Existing sanctions do not appear adequate to prevent deliberate extension of depositions in order to create expense. Taxing the costs of clepositions against the losing party does not provide an effective check. Courts have allowed costs where the depositions have been used in evidence, or where they have dealt with matters directly related to the issues tried. ${ }^{68}$ But costs do not loom large in contrast to the stakes involved in cases where violations are apt

the full advantages of liberal procedure, the availability of expensive depositions together with free rein for irresponsible settlements can only act to encourage suits brought in bad faith purely for their settlement value.

Settlements are the rule rather than the exception in derivative actions. One large plaintiff stockholders' law firm in New York has not taken a derivative action on to the trial stage since the deposition provisions were adopted in the Federal Rules in 1938. For some indication of what these settlements involve see table of disposition of derivative suits in Hornstein, stipra note 53 , at $15-17$.

55. The Rule provides: "If the parties so stipulate in writing, depositions may be taken before any person, at any time or place, upon any notice, and in any manner and when so taken may be used like other depositions."

56. See Ragland, Discovery Before Trial 172 (1932) ; 2 Moore, Federal Practice: 2560 (1st ed. 1938).

57. Although office stenographers may be used occasionally for short depositions, their inability to take notes at more than slow dictation speed and their unfamiliarity with different voices and consequent requests for repetition make their use for this purpose unsatisfactory. Stenographers' notes sometimes are not transcribed where depositions are taken only to perpetuate testimony or where a case is settled before trial; much more frequently they must be transcribed in order to make them available for possible impeachment of witnesses or for study in preparing for trial and for cross-examination.

58. Rule 54(d) provides for the taxing of costs against the losing party as a matter of course, subject to a measure of discretion in the trial judge. The inclusion of depositions in the costs is also up to the discretion of the trial court. Harris v. Twentieth Century-Fox Film Corp., 139 F.2d 571 (2d Cir. 1943) (summary judgment). However, the local court rules can limit their inclusion to cases in which the depositions are offered in evidence. Amerman v. Butte Copper \& Zinc Co., 9 F.R.S. 26a.71, Caso 2 (D. Mont. 1945). Costs of depositions are not taxable as of right. Republic Machine Tool Corp. v. Federal Cartridge Corp., 9 F.R.S. 26a.71, Case 3 (D. Minn. 1946) (costs refused; "They did not help anyone else solve any of the issues submitted to the court.").

The cost of depositions has been included where examination was in "fair range of the issues," Donato v. Parker Pen Co., 9 F.R.S. 26a.71, Case 1 (E.D.N.X. 1945) ; if not unreasonable at the time of taking, Quaker Oats Co. v. Gencral Mills, Inc., 7 F.R.S. 26a.71, Case 2 (N.D.I11. 1943) ; where "reasonably necessary," even though action disposed of by summary judgment, Curacao Trading Co. v. Federal Ins. Co., 7 F.R.S. 26a.71, Case 1 (S.D.N.Y. 1942); if so stipulated, even though not used at trial, Liebert v. Netheriands American Steam Navigation Co., 5 F.R.S. 26a.71, Case 2 (S.D.N.Y. 1942); despite the fact that subsequent pre-trial conference had eliminated need for the depositions, Federal Deposit Ins. Corp. v. Fruit Growers Service Co., 2 F.R.D. 131 (E.D. Wash. 1941) ; where taking of depositions reasonably necessary, Schmitt v. Continental-Diamond Fibre Co., 2 F.R.S. 26a.71, Case 1 (N.D. Ill. 1940). 
to occur. Furthermore, punitive costs could not easily be justified as long as protective orders theoretically are available to prevent abuse. Holding counsel personally liable for excessive costs might be more effective. The judicial code already provides for such liability when costs are "unreasonably and vexatiously" incurred. ${ }^{59}$ But these tests can be proved only in the most extreme cases. Sanctions against lawyers who use the thrent of expensive depositions for shakedowns in the form of settlements are limited to disbarment proceedings. Their administration by fellow lawyers is apt to limit application to the most blatant violations.

Unnecessary and unreasonable expense should be specifically incorporated into Rules 30 (b) and (d) as grounds for a protective order. The Advisory Committee on Rules of Civil Procedure recommended such an amendment in 1946 but it was not adopted by the Supreme Court. ${ }^{00}$ Under the present Rules, courts have the power to issue protective orders against inordinate expense, but only on the basis of "annoyance, embarrassment, oppression and bad faith." These concepts are difficult to measure, and their application has been narrowly confined. Specific inclusion of "expense" in Rules 30 (b) and (d) should produce more frequent and effective protection. ${ }^{01}$

Delay

The breadth of examination permitted under the Rules, together with the inability of deponents to get protection under Rules 30 and $3 \%$, permits examiners to prolong unduly the pre-trial stages of litigation. These delays can be used either to postpone the other party's depositions or to postpone the trial itself. Like expense, delay plays an important role primarily in sizeable and complex suits of the antitrust, breach of contract, and breach of warranty variety.

Delay in the process of taking depositions defeats the purposes of procedural reform. Obviously it hampers speedy disposition of cases. It improperly encourages settlements by keeping parties away from their normal business activities. And it gives the examining party an unfair advantage by forcing the deponent to postpone his preparation for trial.

The more affluent party can create delay by conducting an unnecessarily broad examination, thereby exerting pressure on his weaker adversary. But where the strong party is anxious to get to trial, a weaker opponent can also play the delaying game to advantage-as long as he can afford the time and expense involved. Since the conduct of the deposition is entirely controlled by the judgment and manners of counsel, witnesses can hedge and disputes can arise which would not be possible under the eye of a judge anxious to move

59. 28 U.S.C. $\$ 1927$ (1948).

60. Moore's Federat Rules and Official Forars 1118 (1949).

61. Such an amendment would also provide the same standards for the protection of deponents in oral examinations as exist for parties on whom written interrogatories are served. Rule 33 provides: ". . . The number of interrogatories or of sets of interrogatories to be served is not limited except as justice requires to protect the party from annoyance, expense, embarrassment, or oppression. ..." 
along and get to the point. ${ }^{62}$ Refusals to answer which necessitate court rulings cause further delays. In long depositions this usually means an adjournment, preparation of a transcript, and waiting until the judge will hear the motion. ${ }^{63}$

Courts have sometimes taken affirmative action to check these abuses. Appointment of a master ${ }^{64}$ to supervise proceedings has effectively reduced wrangles between counsel. If vested with the same powers as the trial judge, the master can rule on objections to questions, thereby saving the time consumed in preparing the record, going to court, familiarizing the judge with the extent of the examination so far, and obtaining a ruling. ${ }^{05}$ Occasionally a judge himself may supervise the taking of the depositions. He can this keep them in bounds and at the same time familiarize himself with the case. ${ }^{10}$ These arrangements, however, are either expensive in the one case or burdensome on the courts in the other. There are many cases where the scope of examination is unreasonable, but not enough so to warrant sttch costly stupervision.

62. The deponent can "take the matter under consideration" when requests as to the identity of relevant documents are made, and make the same evasive answer whenever such a request is repeated. In one case where a motion was made for the appointment of a master in order to supervise the conduct of a deposition, one ground for the motion was that the deponent had answered questions with "I don't remember" or "I don't recollect" more than 1800 times in 2000 pages of deposition transcript.

There is no converse motion under Rule 30 (b) to protect the examiner from the delaying tactics of the deponent. KENNEDY, op. cit. supra note 49, at 33. Apparently only the appointment of a master can come close to providing an adequate protection when the deponent decides to hedge.

63. An extreme example of frequent trips to court to settle questions arising out of the conduct of depositions is Deller v. F. K. Porter Co., Civil No. 38-620 (S.D.N.Y. filed Nov. 12, 1946), where 28 court orders pertaining to depositions were issued, in the course of which 13 different judges sat on the various motions.

64. E.g., Laverett v. Continental Briar Pipe Co., 25 F.Supp. 790 (E.D.N.Y. 1939); Hirsch v. Glidden Co., 79 F.Supp. 729 (S.D.N.Y. 1948). In one case the appointment of a master was not allowed without a showing that the examination was sought in bad faith or would be conducted with an intent to annoy, embarrass or oppress the deponent. Michels v. Ripley, 1 F.R.S. 30b.343, Case 1 (S.D.N.Y. 1939). But this requirement scems to be unnecessarily strict.

A master may also be appointed to protect the examiner from the misbehavior of the deponent, and to compel responses to questions. See note 62 silpra.

65. An effective order accomplishing these ends in the appaintment of a master may provide for the following powers: (1) To supervise the conduct of the taking of said depositions, including the length thereof; (2) To rule upon all applications for relief available to and which may be made by any party, during or in connection with the said depositions under Rules 26 through 37 (a), and Rule 45(a) through (d) of the Federal Rules of Civil Procedure.

It should further provide that any action taken or ruling made by the Special Master shall be subject to review by the judge making the appointment upon the application of any party. Parties are not likely to abuse this privilege: it is not profitable to annoy the prospective trial judge.

66. This was dome in United States v. Morgan, Civil No. 43-757 (S.D.N.Y. filed Oct. 30,1947 ) by order of Judge Knox, Feb. 16, 1948. For a discussion of the procedure in that case see Report of the Judicial Conference of the United States 10-12 (1948). 
Elimination of these delays requires affirmative corrective measures. Rule 30 might be amended to require leave of court for depositions of more than five days duration. Power should be vested in the judge to limit the deposition or to appoint a supervising master when he grants the application. ${ }^{6 i}$ Five days appears to be the appropriate dividing line. This limitation would affect only a small percentage of cases. The overwhelming bulk of depositions only rarely run as long as three or four days. The petition for leave to take the deposition should state the subject matter for inquiry in order to provide the prospective deponent with grounds on which to base an argument for limitation. Insofar as possible the court should issue an order limiting the scope or time length of the depositions rather than appoint a master, to avoid the extra expense. But when the proposed scope listed in the application merely restates the allegations in the complaint, appointment of a master may be necessary, for limitation in advance would be virtually impossible. Many complex actions where delays and objections may be anticipated are clearly cases within the scope of Rule 53 authorizing appointment of a master in exceptional circumstances, ${ }^{\text {,9 }}$ for here courts alone cannot provide adequate supervision. If a master is not appointed when leave to take the deposition is granted, the court should be empowered to appoint one on any subsequent motion by either party. ${ }^{69}$

Maintaining a roster of standing masters available to supervise depositions

67. This suggestion has many of the advantages and few of the failings of the "prediscovery" conference recommended in Commentary, Pre-Trial as to Discoztry, 5 F.R.S. 16.266 (1942). The remedy suggested there was a pre-trial conference held at the initial stage of litigation with the dual function of narrowing the issues and prescribing the scope of discovery, thereby avoiding unnecessary expense and delay. Such a solution appears impracticable as an effort to simplify issues since the parties would not yet be sufficiently apprised of the facts to be-able to evaluate their claims and defenses. Furthermore, it would not prove satisfactory in determining the scope of examination in cases where the need for limiting scope appears only after depositions have been instituted.

68. Rule 53(b) provides that reference to a master "shall be the exception and not the rule."

69. This method of eliminating delays might be accomplished by an amendment to Rule 30 similar to the following:

(h) Application for Examination of More than Frne Days Duration; ApromitMENT OF MASTER.

A party desiring to take the deposition of any person by oral examination which will have a duration of longer than five days shall apply to the court for leave to talse the deposition. The application shall state the time and place for taking the deposition and the subject matter to be examined into. Reasonable notice in writing of the time set for hearing the application, together with a copy thereof, shall be served on all parties. The court after hearing such application may make any order provided for in subdivision (b); or may order limitation of the scope or the duration of the proposed deposition or both; or may appoint a master to supervise the examination, with power to rule on all matters arising under Rules 26 through 37 (a), and Rule 45 (a) through (d). Any action taken or ruling made by the master shall be subject to review by the court upon the application of any party, and the cost of the master shall be borne by the party making application for leave to take the deposition, subject to being taxed as costs at the discretion of the court under Rule 54(d). The court may appoint a master to supervise the examination at any subsequent motion of any party or of the deponent. 
in busy jurisdictions would facilitate elimination of delays and other abuses arising from the present unrestricted scope of examination. The cost of the master should be borne initially by the party making application to take the deposition, subject to being taxed as costs of litigation. Imposing this cost would cool the enthusiasm of a party seeking to use the expense of extended depositions to force a settlement where he does not really intend to carry his case on to trial.

\section{Order of Taking Depositions}

The abuses of expense and delay are accentuated when one party gains the right to take depositions before the other. Since the party who has priority is usually entitled to complete his depositions before the deponent can take his in turn, the examiner can tie the deponing party down to his story while securing the material and time to coach his own witnesses effectively. In those cases where depositions are short the effect of priority is not very great. ${ }^{70}$ Priority, however, becomes an extremely important tactical advantage when depositions are extended. ${ }^{71}$

As originally adopted, the Rules provided that without leave of court neither party could serve notice of a deposition before issue was joined. ${ }^{22}$ This provision enabled the defendant to gain priority in the taking of depositions for almost as long as he liked by serving notice along with his answer. Moreover, whatever delays he could create before filing his answer would protect him that much longer from the plaintiff's depositions. ${ }^{73}$ The Rules have since been amended. ${ }^{74}$ Today a plaintiff can serve his notice to take depositions twenty days after the institution of the action, and a defendant can serve his notice at any time. ${ }^{75}$ While no longer able to secure any advantage by delaying his answer, a defendant can still gain priority by serving his notice during the twenty day period of grace.

Courts generally grant absolute priority to whichever party serves his notice for depositions first. ${ }^{76}$ While not inflexible, this rule is so well established

70. In the majority of cases few depositions are taken. In over $80 \%$ of the 1941 cascs in New York in which depositions were sought of parties the deposition of only one person was taken. When depositions were sought of persons other than parties, $60.8 \%$ of plaintiffs and $55.6 \%$ of defendants took no more than two. Stockman, op. cit. supra note 7 , at 32 .

71. KocH, op. cit. stpra note 2 , at 20.

72. Leave to take depositions before the answer has been served usually has been refused. E.g., Munson Line v. Green, 6 F.R.D. 14 (S.D.N.Y. 1946) (plaintiff alleged that defendant would serve notice with his answer thereby gaining a priority which would be used for delay).

73. MOORE's Federal Rules ANd Official Forars 1108 (1949).

74. Ibid. The amendments took effect March 19, 1948.

75. Rule 26(a). A recent case under the amended Rule shows a more liberal approach to the "leave of court" exception than heretofore. Keller-Dorian Colorfilm Corp. v. Eastman Kodak Co., 13 F.R.S. 26a.16 (S.D.N.Y. 1949) (leave to serve notice of depositions along with complaint upheld; defendant already represented by counsel).

76. E.g., Shamokin Woolen Mills v. Cortille Fabrics, 4 F.R.S. 30b.33, Case 1 (S.D.N.Y. 1941); Bough v. Lee, 1 F.R.S. 30b.33, Case 2 (S.D.N.Y. 1939); Grater v. 
that an alert party can gain an advantage which he can combine with an overextensive use of depositions to harass the adverse party. ${ }^{77}$ A matter of a few hours' difference in serving notices may mean the granting of the right to take uninterrupted depositions for many months. ${ }^{78}$

Mere diligence of parties in serving notice should not determine the order of taking depositions. Where disputes over priority arise, courts should allow counsel to suggest feasible arrangements for taking turns in their examinations. The inequitable advantages of priority should be eliminated by ordering parties to stagger the taking of depositions. ${ }^{70}$

Use of an alternating scheme in taking depositions should cut down unnecessary expense and delay..$^{80}$ Both the possibility of immediate reprisals and the inability to gain advantage from postponing the other party's depositions will act to remove much of this abuse. Furthermore, such an arrange-

Schenley Products Co., 26 F.Supp. 768 (S.D.N.Y. 1938). Priority on the basis of diligence is not inflexible and has been defeated where special circumstances have existed: Kenealy v. Texas Co., 29 F.Supp. 502 (S.D.N.Y. 1939) (defendant served notice first, plaintiff defaulted and subsequently served his notice; priority to plaintiff, defendant's remedy for default lies under Rule 37(d)). Contra, on similar facts: Producers Releasing Corp. de Cuba v. P.R.C. Pictures, 8 F.R.D. 254 (S.D.N.Y. 1948).

77. Priority cannot be defeated on the ground that arrangements have previously been made by the other party for taking depositions, or that the depositions will clear up a dispute as to jurisdiction, Modigliani Glass Fibers v. Glastoss MIfg. Co., 7 F.R.D. 647 (E.D.N.Y. 1948); nor by motions by the adverse party challenging the sufficiency of the complaint, Hillside Amusement Co. v. Wamer Bros. Pictures, 5 F.R.S. 30b.33, Case 1 (S.D.N.Y. 1942).

78. In one case notice was served by the defendant in late afternoon and by the plaintiff the very next morning. The defendant was granted priority to talse depositions expected to last well over a year.

79. Rule 30 (b) should be amended to allow the issuance of protective orders governing the order of taking depositions. The Rule should include a provision similar to the following: ". . . or that the order of taking depositions shall be fairly divided between the parties, ...." In considering possible arrangements for an equitable division courts will have to rely on suggestions made by counsel. The factors vary too much in cach case to justify a fixed rule. Order might be established on the basis of who has the burden of proof as to each matter sought to be explored. Under this test the esamination of each witness once begun should not be cut of immediately after the affirmative matter has been inquired into, if there are other matters on which the vitness can testify, unless the additional matter would unreasonably extend the deposition. Order might be determined on the basis of separate allegations, permitting one party to take depositions first and then the other. This assumes, of course, that the evidence supporting or rebutting cach allegation can be easily segregated from evidence necessary to other allegations. It assumes further that witnesses will not have to be recalled to answer questions as each allegation is inquired into. Where the depositions will be of approximately cqual length, the order may be staggered by allowing one party to take the deposition of a witness and then the other party to take the deposition of a different witness. Order could also be determined in units of time, allowing one party to take depositions for a week or a month and then allowing the other party to take depositions for a like period. The unit of time, however, should not be so inflexible that it would necessitate cutting off a deposition before it is completed.

80. Staggering the taking of depositions evenly is not practicable where one party 
ment will permit the preparation for trial by both parties to go ahead at an even pace. It will remove much of the opportunity for coaching witnesses on the basis of what has been learned from the opposing party's case.

\section{Improper Scope}

The virtually unrestricted examination under Rule 26 permits malicious, as well as over-extended, questioning. The abuse can take various forms. It can consist of a long series of annoying questions used to harry the deponent. It can involve a probing into personal matters possessing a blackmail value. Or it can be used to gather valuable trade secrets from the deponent. Whatever the form, the possibility of abuse is created by the inadequacy of protective orders and the inefficacy of self protection through refusal to answer improper questions.

A clever examiner can pose a string of improper questions which are individually not serious enough to merit a deponent's refusing to answer, considering the expense and delay of a trip to court. The cumulative effect of these, however, can constitute a vigorous bullying campaign. Such tactics are available in cases like stockholders' suits, where plaintiff's information comes from corporate insiders. A defendant can worry the plaintiff with questions about the source of his information and about the basis on which his counsel is retained. Under such circumstances Rule 30 (d) cannot protect a deponent, since its requirement of bad faith is too difficult to establish.

Blackmail material can be uncovered not only by probing into embarrassing personal matters, ${ }^{81}$ but also by unearthing other causes of action against the deponent. Though not directly of use to the examiner, the information may be troublesome if revealed to third persons. ${ }^{82}$ Discovering such matters gives the examiner a bludgeon to force settlement or withdrawal of the action.

seeks considerably more depositions than the other. The ratio of depositions sought varics with the type of case.

\begin{tabular}{lccc}
\multicolumn{4}{c}{ Depositions taken of Persons other than Parties (1941) } \\
& By Plaintiff & By Defendant & By Both \\
Jones Act & $27.9 \%$ & $44.1 \%$ & $27.9 \%$ \\
Negligence & 59.7 & 31.9 & 8.3 \\
Contract & 60.0 & 24.2 & 14.2
\end{tabular}

These figures include depositions sought of corporate employecs where the corporation was a party. The percentage of depositions which were taken of corporation employecs was over $50 \%$ in Jones Act cases, $63.9 \%$ in negligence cases, and $68.6 \%$ in contract cascs. STOCKaran, op. cit. silpra note 7, at 31-2.

81. Ragland recognized this possibility primarily in actions for seduction under prom* ise of marriage and for malicious prosecution. RagLANd, Discovery Before TRIAL 31 (1932). His solution was to prevent the publication of the results of the examination. Id. at 30 . But this solution does not avail much where the mere fact that the knowledge is in the hands of the other party is enough to create a threat.

82. As to how this might arise, see Checker Cab Mfg. Corp. v. Checker Taxi Co., 3 F.R.D. 228 (D. Mass. 1943). There the defense to a contract action was that the contract was void because it violated the antitrust laws. In permitting examination into plaintiff's possible violation of these laws the court endeavored to protect the plaintiff by limiting the use of the information: "As the inquiry seems to be a rather searching one, and sitce it is 
One potentially serious abuse is the extraction of trade secrets not essential to the action at the deposition stage. This possibility is most likely to materialize in patent infringement suits. Although in many patent cases the offending product is on the market and freely accessible to anyone, in others the alleged infringement relates to secret chemical processes or the methods and machinery of manufacture. The patentee-plaintiff usually brings the infringement action against a competitor. Extraction of trade secrets from that competitor could well provide the patentee with an unfair business advantage, whether he wins or loses the infringement action. Although the extent to which patentees exploit this advantage is necessarily a matter of speculation, patent lawyers fear that the discovery of secret processes may be improperly used to jeopardize their clients' business status.

Courts have not been consistent in dealing with the protection of trade secrets. ${ }^{83}$ Sealed answers, one of the protective measures authorized by Rule 30 (b) have seldom been ordered for the purpose. In order to gain what protection they can counsel generally instruct witnesses not to answer questions concerning trade secrets unless ordered to by the court under Rule 3\%.

Elimination of the abuses of improper scope can be accomplished primarily by corrective measures designed to prevent delays in the deposition-talking process. ${ }^{85}$ To these should be added changes in the administration of the existing Rules. To curtail bullying and other improper questioning, protective orders should be more freely granted. ${ }^{86}$ When a deponent has refused to answer a question which involves a trade secret, courts should change their approach from one of ordering revelation, subject to final determination if the answer is presented at trial, to one of protecting the secret, ordering its dis-

being made purely as a matter of defense to an action on a contract, the use of any information developed through the inquiry is limited strictly to the present case." Id. at 229. But query as to the effectiveness of this attempt at protection.

83. Revelation has been ordered in Cooney v. Guild Company, 3 F.R.S. 26b.46, Case 1 (S.D.N.Y. 1940) ; Radio Receptor Co. v. General 1Lotors Corp., 2 F.R.S. 30b.35, Case 2 (S.D.N.Y. 1939). In other cases the trade secret has been protected, especially where not essential to the case: Hirshhorn v. Mine Safety Appliances Co., 8 F.R.D. 11 (W.D.Pa. 1948) (secret research data) ; Lenerts v. Rapidol Distributing Co., 6 F.R.S. 30b.352, Case 1 (S.D.N.Y. 1942) (hair dye formula).

The definition of what is secret has been strictly construed: MIoss v. Actna Standard Engineering Co., 11 F.R.S. 30b.352, Case 1 (E.D.N.Y. 1948) (sources of supply for manufacturing parts not protected).

84. Apparently only one published case has suggested the use of sealed documents to protect trade secrets from a competitor. Remington Rand v. Control Instrument Co., 7 F.R.D. 18 (E.D.N.Y. 1947) (drawings and specifications of an invention).

85. Note 69 sipra.

86. District judges should not be bound by stingy precedents in issuing protective orders under Rules 30 (b) and (d). If, however, the courts do not liberalize the trend of these earlier cases of their own accord, the Advisory Committee on the Federal Rules should change the language of the Rules to call attention to the desirability of issuing protective orders more freely. This might be accomplished as simply as by changing the word "may" to "shall" in 30 (b) and (d), or by making the final clause in 30 (b) a separate sentence. 
closure only if it appears necessary at trial. ${ }^{87}$ Finally if there are so many ap. plications for rulings under Rules 30 (d) and 37 that judges cannot adequately study the transcript of the depositions, applications might be referred to specially empowered standing masters. ${ }^{88}$

\section{CONCLUSION}

The deposition provisions of the Federal Rules have proved their worth in promoting just settlements and informed preparation for trial. This success, however, has been marred by abuses: unnecessary expense, delaying tactics, unfair advantage in taking depositions, and malicious questioning.

Changes should not be advocated without cautious consideration. But the following corrective measures should eliminate much of the present abuse of the deposition procedure without defeating its basic purposes :

1. The inclusion of "expense" as a basis for protective orders under Rules 30 (b) and (d);

2. An amendment to Rule 30 requiring leave of court for depositions lasting more than five days, and permitting the court at its discretion to limit the scope and/or the length of the deposition, or to appoint a master to supervise the deposition;

3. Determining the order of taking depositions on grounds other than the diligence of counsel in serving notice;

4. A greater inclination on the part of courts to sustain deponents under Rule 37 who in good faith refuse to answer questions deemed improper, referring long transcripts to standing masters.

87. This procedure appears to have been followed in at least one case. Lever Bros. Co. v. Proctor \& Gamble Mfg. Co., 38 F.Supp. 680 (D.Md. 1941) (chilling process for Ivory soap need not be revealed unless relevance appears at trial).

88. Reference to a master has been ordered in at least one instance to hear and decide objections to written interrogatories. Waldo Theatre Corp. v. Dandis, 4 F.R.S. 53b.12, Case 1 (D. Me. 1941). 